\title{
Toponimiye Mührünü Vuran Selçuklular: 1/200.000 Ölçekli Türkiye Topografya Haritalarındaki Han ve Kervansaray Adlı/Ekli Yer ve Yerleşme İsimleri Üzerinden Bir Değerlendirme ${ }^{1}$
}

\author{
Osman GÜMÜŞÇ:̈ ${ }^{1}$ iD İlker YİĞíT ${ }^{2}$ \\ 1. Prof. Dr., Çankırı Karatekin Üniversitesi, Edebiyat Fakültesi, Coğrafya Bölümü, Çankırı, Türkiye, ogumuscu@ yahoo.com \\ 2. Dr. Öğr. Üyesi, Burdur Mehmet Akif Ersoy Üniversitesi, Fen Edebiyat Fakültesi, Coğrafya Bölümü, Burdur, Türkiye, \\ iyigithg@gmail.com (Sorumlu Yazar/Corresponding Author)
}

\begin{tabular}{|c|c|}
\hline Makale Bilgileri & ÖZ \\
\hline $\begin{array}{l}\text { Makale Geçmişi } \\
\text { Geliş: } 18.04 .2020 \\
\text { Kabul: } 20.08 .2020 \\
\text { Yayın: } 25.12 .2020\end{array}$ & $\begin{array}{l}\text { Onamastiğin bir alt dalı olan toponimi sahasında çalışan tarih ve coğrafya bilimine mensup araştırmacılar yer ve } \\
\text { yerleşme isimlerine odaklanarak geçmişi anlamaya ve anlamlandırmaya çalışmaktadır. Tarihi coğrafya } \\
\text { sahasında özellikle Selçuklu, Beylikler ve Osmanlı dönemlerine 1şık tutacak toponimi çalışmalarının } \\
\text { yapılmasına ciddi ihtiyaç vardır. Bu noktada eldeki çalışmada da toponimik verilerden hareketle Selçuklu } \\
\text { dönemine, bugünkü Türkiye sınırlarından bakıllarak bir değerlendirme yapılmaya gayret edilmiştir. Çalışma }\end{array}$ \\
\hline Anahtar Kelimeler: & kapsamında kaynak olarak 1900 'lü yılların başında alt yapısı oluşturulan 1/200.000 ölçekli topografya haritaları \\
\hline $\begin{array}{l}\text { Tarihi coğrafya, } \\
\text { Toponimi, } \\
\text { Han, } \\
\text { Kervansaray, } \\
\text { Selçuklu. }\end{array}$ & $\begin{array}{l}\text { kullanılmıştır. Türkiye Cumhuriyeti sınırlarını içine alan } 123 \text { paftada han ve kervansaray adlı/ekli yer ve } \\
\text { yerleşme isimleri taranmıştır. Bu taramalar neticesinde elde edilen bilgiler Arc-Gis ortamına aktarılmak } \\
\text { suretiyle sayısallaştırma gerçekleştirilmiş ve tematik haritalar üretilmiştir. Böylece Selçuklu'nun toponimiye } \\
\text { vurduğu birer damga olan han ve kervansaray isimlerini taşıyan yer ve yerleşme isimlerinin mekânsal dağılışı } \\
\text { yapılmış ve bu dağıllşa bağlı olarak kervan yolları çizilmiştir. Han ve kervansaray adlı/ekli yer ve yerleşmelerin } \\
\text { özellikle Anadolu'nun orta kesimi başta olmak üzere bilinen kervan yollarının yanı sıra alternatif güzergâhlarda } \\
\text { da bulunduğu tespit edilmiş̧ir. }\end{array}$ \\
\hline
\end{tabular}

The Seljuks who Seal the Toponymy: An Evaluation on Named/Affixed Khan and Caravanserai Place and Settlement Names in 1/200.000 Scale Topographic Maps of Turkey

\begin{tabular}{|c|c|}
\hline Article Info & ABSTRACT \\
\hline $\begin{array}{l}\text { Article History } \\
\text { Received: } 18.04 .2020 \\
\text { Accepted: } 20.08 .2020 \\
\text { Published: } 25.12 .2020 \\
\text { Keywords: } \\
\text { Historical geography, } \\
\text { Toponymy, } \\
\text { Khan, } \\
\text { Caravanserai, } \\
\text { Seljuks. }\end{array}$ & $\begin{array}{l}\text { Researchers from the science of history and geography working in the field of toponimi, a sub-branch of } \\
\text { consent, try to understand and make sense of the past by focusing on the names of places and settlements. In the } \\
\text { historical geography area, there is a great need for toponymy studies that will shed light on Seljuks, Beyliks and } \\
\text { the Ottoman periods. At this point, toponymic data from the present study also move to the Seljuk period, every } \\
\text { effort was made to make an assessment looking at the current borders of Turkey. Within the scope of the study, } \\
\text { topography maps with a scale of } 1 / 200.000 \text {, whose infrastructure was established in the early } 1900 \text { s, were used. } \\
123 \text { sheets in border areas into the Republic of Turkey inns and caravanserais named / effixed space and } \\
\text { settlement names are scanned. By transferring the information obtained as a result of these scans to Arc-Gis } \\
\text { environment, digitization was carried out and thematic maps were produced. Thus, the spatial distribution of the } \\
\text { names of places and settlements bearing the names of khan and caravanserai, which are stamped by the Seljuks, } \\
\text { was made and caravan roads were drawn depending on this distribution. It has been determined that khan and } \\
\text { caravanserai named/effixed places and settlements are located in alternative routes as well as known caravan } \\
\text { roads, especially in the central part of Anatolia. }\end{array}$ \\
\hline
\end{tabular}

Atıf/Citation: Gümüşçü, Osman - Yiğit, İlker. "Toponimiye Mührünü Vuran Selçuklular: 1/200.000 Ölçekli Türkiye Topografya Haritalarındaki Han ve Kervansaray Adlı/Ekli Yer ve Yerleşme İsimleri Üzerinden Bir Değerlendirme". Selçuklu Medeniyeti Araştırmaları Dergisi (SEMA) 5 (Aralık 2020), 97-109. https://doi.org/10.47702/sematr.2020.6

"This article is licensed under a Creative Commons Attribution-NonCommercial 4.0 International License (CC BY-NC 4.0)"

\footnotetext{
${ }^{1}$ Bu makale, I.Uluslararası Selçuklu Tarihi Coğrafyası Sempozyumu Suriye, Irak, Filistin adlı sempozyumda
} sözlü bildiri olarak sunulan aynı adlı bildirinin genişletilmiş halidir. 


\section{GİRIŞ}

Yol, insanlar arasında çeşitli mekân/saha münasebetlerini sağlayan, insanların ve ihtiyaç maddelerinin bir yerden başka bir yere taşınmasına imkân veren hayvanlar ile nakil vasıtalarının hareketine müsait arazi şeritleridir. Yer şekilleri, iklim, yükselti, bakı, su, yiyecek ve konaklama temini ile güvenlik gibi faktörlere bağlı olan ulaşım; bilimsel ve teknolojik açıdan XX. yüzyıl başlarına gelinceye kadar çok az değişime uğramıştır. Dolayısıyla, başlangıcından motorlu kara taşıtlarının keşfedildiği XIX. yüzyıl sonlarına kadar, karayollarının durumu ile ulaşım araçlarının aradan geçen binlerce yıla rağmen fazlaca değişmemiştir. ${ }^{2}$ Zamanın şartlarına göre iyi bir ulaşım ağına ve güvenliğine sahip olmak günümüzde olduğu gibi geçmişte kurulan devletler için de önemli olmuştur. Çünkü iyi bir yol sistemi bulunmayan devletler, ancak taşıma masrafı kaldırılabilen kıymetli maddeler (yeterli miktarda üretiliyorsa) başka devletlere satabilirler ve dişardan en gerekli şeyleri almakta büyük güçlük çekerler ve sonuçta kendi sınırlı geçim kaynakları ile yetinmek zorunda kalırlar. Böylece kapalı ekonomi sistemi içerisinde bulunan memleketler adeta dünyadan ayrı ve sönük bir şekilde yaşamaya mahkûm olurlar. ${ }^{3} \mathrm{Bu}$ durum ülkeler arasında böyle olduğu gibi bir ülke dâhilinde de böyledir. Nitekim yolun önemi, üstün standartlara uygun olmasından değil, bir ülke içindeki iki nokta arasında sosyal ve iktisadi ilişkilere imkân hazırlamasından ileri gelir. Bu nedenle yollar hangi bakımdan ele alınırsa alınsın insan vücudundaki "kan damarlarına" benzetile gelmiştir.

Çok eski dönemlerden itibaren siyasi, sosyal ve ekonomik faktörlerin ve jeomorfolojik şartların etkisiyle kurulan kadim bir yol şebekesine sahip olan Anadolu, uzun iskân tarihinde çeşitli medeniyetlere ev sahipliği yapmıştır. Anadolu'nun kadim yol ağı denildiğinde, Asur ticaret kolonileri dönemi, Hitit dönemi, Roma ve Bizans dönemi yolları ilk akla gelenler arasında belirtilebilir. Anadolu'da Türk egemenliğinin sağlanmaya başlamasıyla birlikte devralınan yol ağı; Beylikler, Anadolu Selçukluları ve Osmanlılar zamanında çeşitli iyileştirmelerin yapılmasının yanında yürürlüğe konulan sigorta sistemi ve uygun yerlere han ve kervansarayların yapımı, derbendlerin tesisi ile de daha işlevsel bir hale getirilmiştir. ${ }^{5}$

Anadolu, tarihin ilk dönemlerinden itibaren jeomorfolojik yap1 ve jeopolitik konumu sebebiyle önemli bir ulaşım ağına sahip olmuş, doğu ile batı arasında adeta bir "köprü" vazifesi görmüştür. Anadolu'nun bu özelliğinde, fiziki coğrafya (jeomorfoloji, iklim, su kaynakları vb.) özellikleriyle, farklı sosyo-ekonomik özelliklere sahip medeniyetler arasında bulunması, kısaca "coğrafi konumu" bunda belirleyici olmuştur. ${ }^{6}$ Ulaşım olanakları yalnızca ticari açıdan ve farklı medeniyetlerin etkileşimi açısından değil, aynı zamanda yerleşmelerin kuruluş ve gelişmesinde de oldukça önemli olmuştur. Anadolu sathına bakıldığında ulaşıma elverişli kilit özelliğe sahip noktalarda tarihi süreçte önemli şehirlerin kurulduğu hemen göze çarpar. Türkiye'de morfolojik yapı ve şartlar gereği, kabaca doğu-batı doğrultusunda; yer yer de morfolojinin izin verdiği kesimlerde kuzey-güney yönlü ulaşımın

\footnotetext{
${ }^{2}$ Osman Gümüşçü, XVI. Yüzyll Larende (Karaman) Kazasında Yerleşme ve Nüfus (Ankara: Türk Tarih Kurumu, 2001), 69.

${ }^{3}$ Besim Darkot, Türkiye İktisadi Coğrafyası (İstanbul: İÜ Yayını, 1968), 200.

${ }^{4}$ Osman Gümüşçü- Hüseyin Çınar- Yusuf Kılıç- Abdullah Uğur, Açıklamalı Türkiye Tarih Atlası Projesi (ATTAP) (Ankara: TÜBİTAK, 2011), 69.

5 Osman Gümüşçü-İlker Yiğit, "XIII-XVI. Yüzyıllarda Beyşehir Çevresi Ulaşım Ağı”, Uluslararası Orta Anadolu ve Akdeniz Beylikleri Tarihi, Kültürü ve Medeniyeti Sempozyumu-I Eşrefoğullarl, ed. Mehmet Şeker vd. (Konya: Necmettin Erbakan Üniversitesi Kültür Yayını, 2018), 545.

${ }^{6}$ Hüseyin Çınar- Mehmet Bulut- İlker Yiğit, “Tarihi İpek Yolu'nun Anadolu Güzergahı”, Uluslararası İpek Yolu Kongresi ve 10. ADAM Kongresi (İstanbul: İstanbul Sabahattin Zaim Üniversitesi Yayınları, 2014), 126.
} 
sağlandığı ana güzergâhlar üzerinde geçmişte kurulan yerleşmeler, bugüne değin önem ve avantajlarını sürdürmüşlerdir. ${ }^{7}$

Onamastiğin bir alt dalı olan toponimi sahasında çalışan tarih ve coğrafya bilimine mensup araştırmacılar yer ve yerleşme isimlerine odaklanarak geçmişi anlamaya ve anlamlandırmaya çalışmaktadır. Yazılı kaynakların olduğu dönemlerin yanı sıra yazılı kaynakların az olduğu veyahut hiç olmadığı zaman dilimleri için oldukça kıymetli bir veri seti olarak karşımıza yer ve yerleşme isimleri çıkmaktadır. Zira Anadolu'da yer ve yerleşme isimleri bazı küçük söyleniş değişiklikleri dışında asırlarca önceki durumunu büyük ölçüde koruyabilmiştir. Anadolu sathında birçok şehir yerleşmesinin yanı sıra kırsal alandaki yerleşme isimleri bu hususun delili durumundadır. Hal böyle olunca yer ve yerleşme isimlerine yönelik çalışmalar oldukça önem taşımaktadır. Yazılı belgelerin olmadığı yerlerde açılım sağlayabilen toponimik veriler yazılı belgelerin olduğu yerde de konunun daha derinlemesine anlaşılmasına, farklı cephelerin aydınlatılmasına hizmet edebilmektedir.

Toponimik verilerden hareketle tarihi, siyasi, sosyal, ekonomik vb. birçok konuda araştırma yapmak mümkün olup eldeki bu çalışmada yer ve yerleşme isimlerinden hareketle tarihi ulaşım coğrafyasına ilişkin bir araştırma yapılmaya gayret edilmiştir. Zaman olarak Selçuklu dönemine odaklanılmış, mekân olarak ise Türkiye sınırları göz önünde bulundurularak tarihi yollar detaylandırılmıştır. Çalışma kapsamında kaynak olarak 1900'lü yılların başında alt yapısı oluşturulan 1/200.000 ölçekli topografya haritaları kullanılmıştır. Araştırma dâhilinde Türkiye Cumhuriyeti sınırlarını içine alan 123 adet topografya haritasında han ve kervansaray adlı ve ekli yer ve yerleşme taranmıştır (Fotoğraf 1).

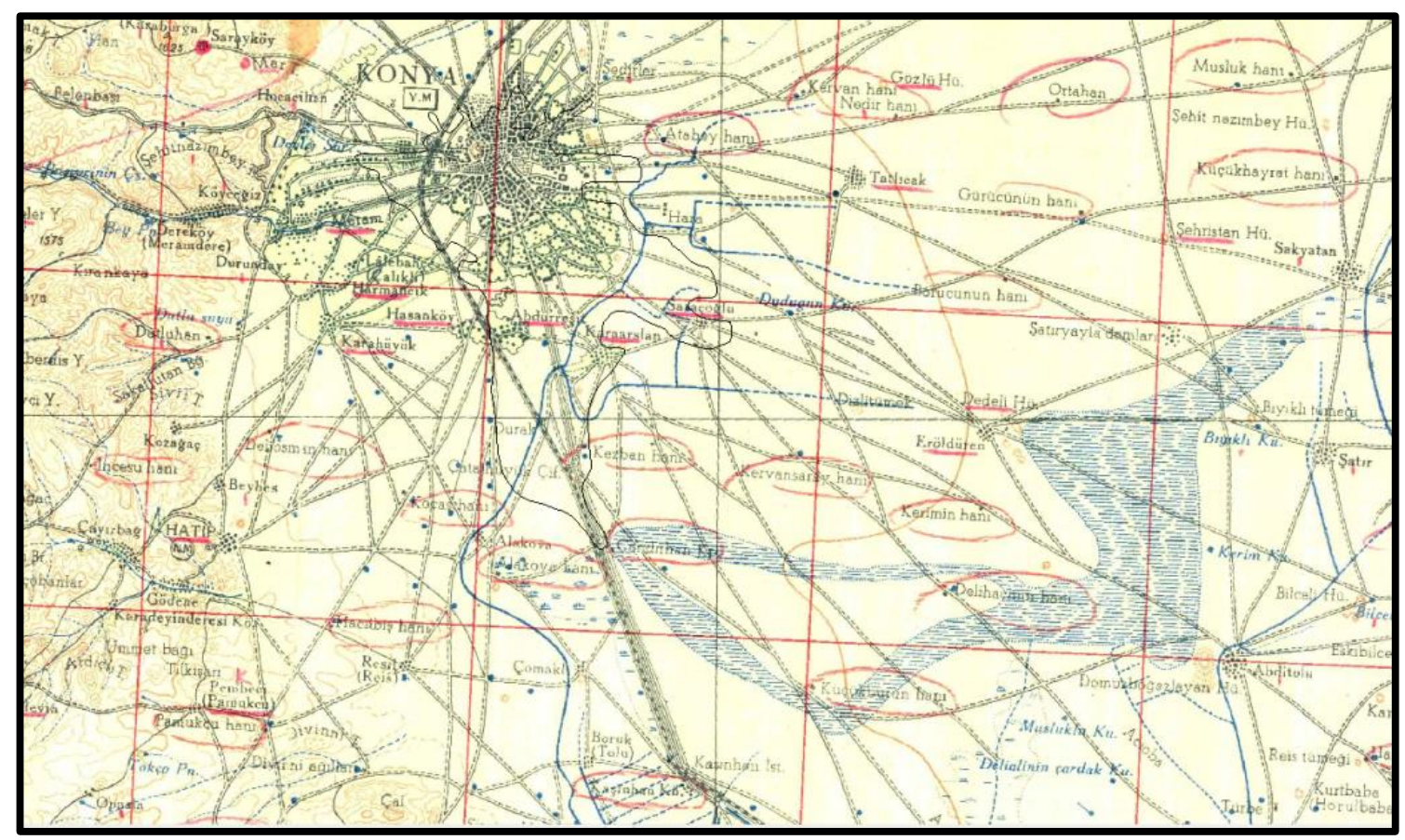

Fotoğraf 1: 1/200.000 ölçekli Konya paftasının bir parçası

Taramalar neticesinde elde edilen bilgiler Arc-Gis ortamına aktarılmak suretiyle sayısallaştırma (raster veri vektör veri haline dönüştürülerek) gerçekleştirilmiş ve tematik haritalar üretilmiştir. Han ve kervansaray ad1//ekli yerleşmeler ile bugüne değin tespit edilen/tescillenen han ve

\footnotetext{
${ }^{7}$ Osman Gümüşçü- İlker Yiğit, "XI-XVI. Yüzyıllarda Cizre ve Çevresinde Ulaşım Ağı”, Uluslararası Bilim, Düşünce ve Sanatta Cizre Sempozyumu, ed. M.Nesim Doru (İstanbul: 2012), 92.
} 
kervansaray noktaları çakıştırılmıştır. Böylece Selçuklu'nun toponimiye vurduğu birer damga olan han ve kervansaray isimlerini taşıyan yer ve yerleşme isimlerinin mekânsal dağılışı yapılarak -farklı bir pencereden- değerlendirme firsatı yakalanmıştır. Han ve kervansarayın mevcut olmadığı ancak toponimik verilerin oldukça yoğunlaştığ1 alanlarda jeomorfolojik yapı göz önünde bulundurulmak suretiyle yeni kervan yolu güzergâhları çizimleri yapılmıştır. Söz konusu güzergâhlar seçilen örneklem alanlar dâhilinde ele alınarak ulaşım haritaları oluşturulmak suretiyle değerlendirilmiştir.

\section{Anadolu’da Selçuklu Mührü: Han ve Kervansaray İsimli/Ekli Yer ve Yerleșme İsimleri}

Türk fütuhatına kadar Bizanslılar döneminde daha çok deniz yollarının kullanılması nedeniyle ticari yönden çok büyük önem taşımayan Anadolu, Akdeniz'in batı, güney ve doğusunun Müslümanların eline geçmesiyle tamamen ticari faaliyet dışında kalmıştır. Müslümanların egemenliğinde iken Akdeniz ticareti Orta Asya'dan Bağdat'a, oradan da Suriye limanları aracılığıla Afrika ve Endülüs'e değin yapılıyordu. Ayrıca Anadolu'nun İslam ve Hiristiyan dünyasının mücadele sahası içinde kalmış olması ticari faaliyete engel olduğu gibi savaşların getirdiği tahribat da iktisadi hayatı olumsuz etkilemiştir. Selçuklu fütuhatı Anadolu'nun Müslümanlar ve Hıristiyanlar arasında bir köprü vazifesi görmesini ve Dünya ticareti bakımından önemli bir yer kazanmasını sağlamıştır. Anadolu'da bu dönemde yollar doğu-batı ve kuzey-güney istikametinde iki ana güzergâhtan oluşuyordu. Bunlardan birincisi, doğu-batı yönünde olanı Antalya ve Alanya'dan başlayarak daha sonra Yumurtalık'a; Konya, Aksaray, Kayseri, Sivas, Erzincan ve Erzurum üzerinden İran ve Türkistan'a ulaşırdı. İkici yol ise, Kuzey-güney yönünde olanı, yine Antalya, Alanya veya Yumurtalık'tan Kayseri yoluyla Sivas'a gelir ve birinci yolla birleşir, buradan Tokat-Sinop veya TokatSamsun güzergâhından deniz yoluyla Kırım'da Suğdak Limanı'na ulaşırdı. Bu yol Elbistan-MalatyaDiyarbakır üzerinden Irak'a bir kol verirdi. Selçuklular bu yollar üzerinde her 30-40 kilometrede, bir menzillik mesafede, kervansaray adı verilen bir kale hüviyetinde konaklama noktaları inşa etmiştir. ${ }^{8}$

Kervansaraylar, geçmişte kervanların güvenliği ve konaklaması için anayol kenarında inşa edilen yapılardır. Kervansaraylar kitabelerinde ve kaynaklarda han veya ribat olarak da isimlendirildiği görülmektedir. Hanlar mal yapımı ve ticaret işlerinin birlikte görüldüğü yerler olup adlarını da burada üretilen mallardan alıyordu. Şehirler üzerindeki yollarda yaptırılan ve kuruluşları bakımından çeşitli ihtiyaçları karşılayacak şekilde olanlara ise kervansaray ismi verilmektedir. İki kervansaray arasındaki mesafe yolun eğim durumuna ve yeryüzü şekillerine göre biraz değişse de 30 $\mathrm{km}$ civarındadır. Kervanlar burada geçici olarak konaklar, beraberlerinde getirdikleri malları pazarlar ve para işlemlerini gerçekleştirirlerdi. ${ }^{9}$ Devlet eliyle ya da hayırsever kişiler tarafından kurulan bu muhkem binalarda kervanların ihtiyaçları ücretsiz karşılanırdı. Kervansarayların içinde yatakhane, aşevi, erzak ambarları, ticari eşyanın konulduğu depolar, ahır ve samanlıklar, mescitler, hamamlar, şadırvanlar, eczaneler, ayakkabı tamir atölyeleri ve nalbantlar bulunurdu. Kervansarayların masrafları ise tesis edilen vakıflar aracılığı ile karşılanırdı. Şehir ve kasabalarda ticaret kafilelerinin ihtiyaçlarını karşılamak üzere ayrıca hanlar yapıılmıştı. ${ }^{10}$

Selçuklu sultanları, Konya merkez olmak üzere Anadolu'nun doğu ve batı yönü yanı sıra kuzey ile güney limanları arasında ulaşım bağlantısını kurmak yoluyla ekonomi için çok önemli hizmetler gerçekleştirmiştir. Kırım-Rusya-Suriye-Mezopotamya arasındaki kuzey-güney yolu ile doğudan gelerek İstanbul, Ayasuluk, Foça limanlarında son bulan ve Orta Asya-Hindistan-İran-

\footnotetext{
${ }^{8}$ Yusuf Halaçoğlu, “Anadolu/Ulaşım ve Yol Sistemi”, Türkiye Diyanet Vakfi İslâm Ansiklopedisi (İstanbul: TDV Yayınlar1, 1991), 3/127.

9 Şebnem Akalın, "Kervansaray". Türkiye Diyanet Vakfi İslâm Ansiklopedisi (İstanbul: TDV Yayınları, 2002), 25/299-300; Koray Özcan, “Anadolu'da Selçuklu Kentler Sistemi ve Mekansal Kademelenme”, METU. JFA, 23/2 (2006), 30-31.

${ }^{10}$ Muharrem Kesik, "Selçuklular Zamanında Anadolu”, Coğrafya (Ankara: TÜSİAD Yayınları, 2002), 148.
} 
Avrupa yönünde uzanan doğu-batı milletlerarası ticaret potansiyelini Anadolu'ya kazandırmıştır. ${ }^{11}$ Selçuklu dönemine ait ve bugüne dek varlığı belirlenen 232 kervansarayın Anadolu topraklarındaki dağılışı incelenirse (Harita 1), Selçuklu üretim-dağıtım sisteminin, doğu-batı ve kuzey-güney milletlerarası ticaret yolları olmak üzere iki eksende odaklandığı söylenebilir. Bu eksenlerden birincisi, Ayasuluk, Foça veya İstanbul'dan gelen ve Konya'da odaklanarak Aksaray-Kayseri-Sivas-ErzincanErzurum-Iğdır yoluyla Tebriz'e uzanan doğu-batı ticaret yoludur. Eksenlerden ikincisi ise Antalya veya Alaiyye ya da Ayas (Yumurtalık) başlangıç olmak üzere Konya'dan Ankara-Çankır1-KastamonuSinop veya Konya-Aksaray-Kayseri üzerinden Sivas'ta dügümmlenerek Tokat-Amasya yoluyla Sinop ya da Samsun limanlarına ulaşan kuzey-güney ticaret yolu güzergâhıdır. ${ }^{12}$

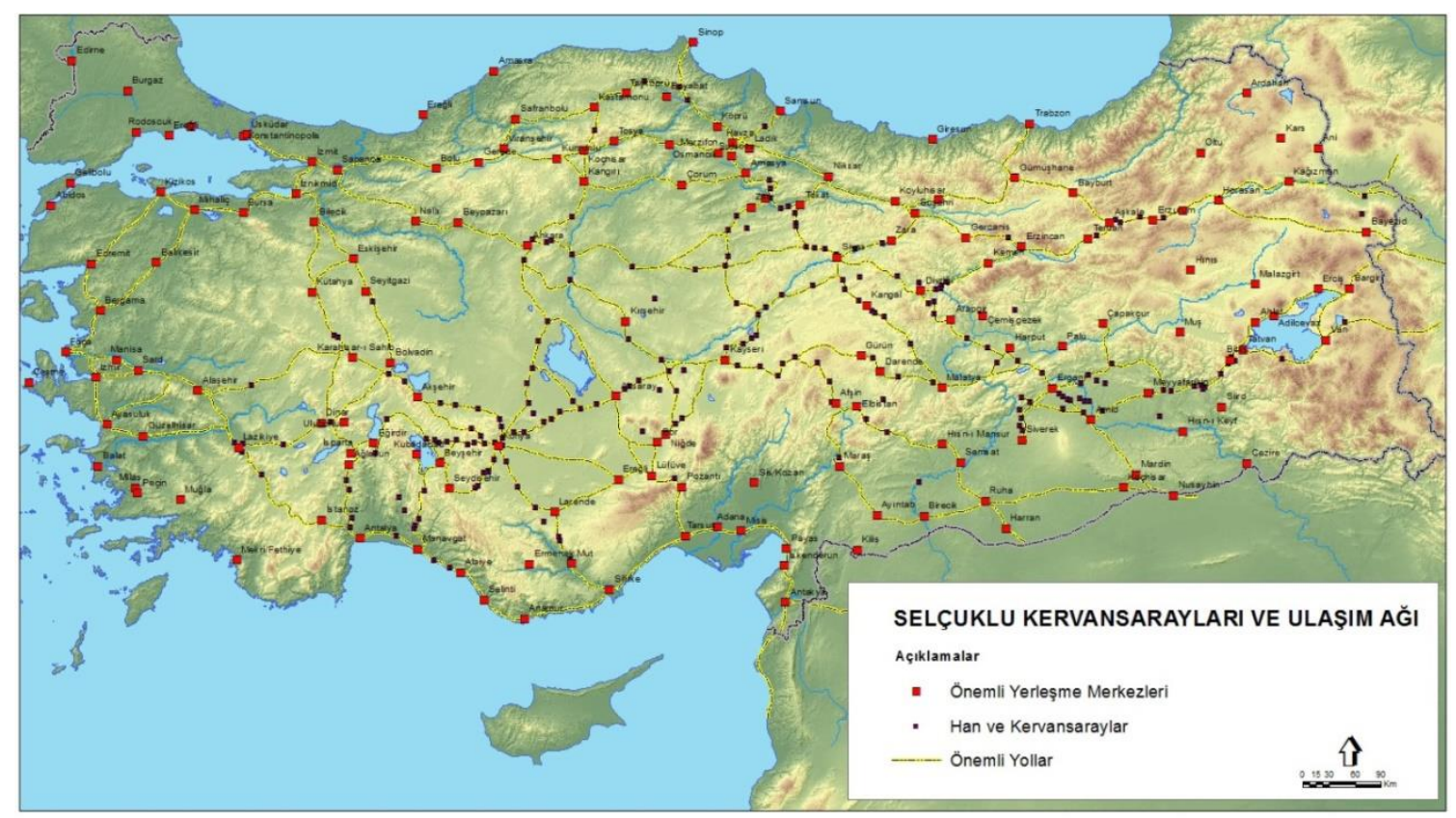

Harita 1: Selçuklu kervansarayları ve ulaşım a $\breve{g ̆}^{13}$

Yukarıda verilen haritada belirli güzergâhların ön plana çıktığı bazı sahalarda ise han ve kervansarayın olmadığı (en azından bugüne ulaşmaması sebebiyle bilginin mevcut olmadığı), dolayısıyla da yolun olup olmadığ ya da nerden geçtiği belirsizliğini korumaktadır. Bu noktada toponimik veriler ciddi bir çıkış sağlamaktadır Zira farklı bölgelerde kara içinde ve kıyı bölgeleri iç bölgelere bağlayan çeşitli güzergâhların mevcut olduğu anlaşılmaktadır. 1/200.000 ölçekli topografya haritalarında yapılan taramalar neticesinde ortaya çıkan belli başlı güzergâhlar şu şekilde belirtilebilir:

\footnotetext{
${ }^{11}$ Özcan, "Anadolu'da Selçuklu Kentler Sistemi ve Mekansal Kademelenme”, 30-31.

${ }^{12}$ Gümüşçü vd., Açıklamalı Türkiye Tarih Atlası Projesi (ATTAP), s. 245.

13 Yavuz Tiryaki, Türk Dünyası Kültür Atlası (Selçuklu Dönemi 2) (İstanbul: Türk Kültürüne Hizmet Vakfı 1998); O. Cezmi Tuncer, Anadolu Kervan Yollarl (Ankara: Vakıflar Genel Müdürlüğü Yayınları, 2007); Hakk1 Acun, Anadolu Selçuklu Dönemi Kervansarayları (Ankara: Kültür ve Turizm Bakanlığı Yayınları, 2007); İsmet İlter, Tarihi Türk Hanları (Ankara: Karayolları Genel Müdürlüğü, 1969); Kurt Erdmann, Das Anatolische Karavansaray des 13. Juhrhunderts I (Berlin: 1961); Kurt Erdmann - Hanna Erdmann, Das Anatolische Karavansaray des 13. Juhrhunderts II-III (Berlin: 1976); M. Kemal Özergin, "Anadolu'da Selçuklu Kervansarayları”, İstanbul Üniversitesi Tarih Dergisi XV/20 (1965), 141-170; Osman Turan, "Selçuklu Kervansarayları", Belleten X/39 (1946), 471-496; Gümüşçü vd., Açıklamalı Türkiye Tarih Atlası Projesi (ATTAP).
} 


\section{Akdeniz Sahil Şeridini İç Bölgeler Bağlayan Kervan Yolu Güzergâhları}

Tarihi süreçte Akdeniz'in kuzey sahil şeridinde Antalya, Alaiye, Silifke, Tarsus, Adana ön plana çıkan önemli şehirlerarasında yer almaktadır. Birer liman kenti olmaları hasebiyle deniz yolu taşımacılığında ön plana çıkmakla birlikte kara içlerini deniz aşırı şekilde diğer bölgelere bağlayan birer kavşak mesabesinde de olduğu söylenebilir. Bu şehirlerden kuzey yönünde iç bölgelere ulaşan çeşitli yol güzergâhları mevcuttur.

1/200.000 ölçekli topografya haritalarında yapılan taramalar neticesinde tescilli han ve kervansarayların dışında Akdeniz sahil şeridinden iç bölgelere alternatif güzergâhların olduğu dikkati çekmektedir. Tescilli han ve kervansaraylara göre bilinen yol güzergâhı Antalya şehrinin kuzeyinden bir kol Kırkgöz Han ve Döşeme Boğazı marifetiyle Toros Dağları'nı aşıp Susuz Han, İncir Han üzerinden Ağlasun üzerinden Isparta’ya ve Çeltikçi Belini aşarak da Burdur'a ulaşmaktadır. Antalya kuzeyine doğru devam eden diğer yol ise Korkuteli (İstanoz) üzerinden Lazikiye (Denizli) istikametine devam etmektedir. Manavgat üzerinden kuzeye devam eden yol Eynif ve Kembos polyeleri üzerinden Beyşehir'e ulaşmaktadır. Ancak bu noktada Köprülü Kanyon Havzası dâhilinde bir yol olduğu ve bu kervan yolunun tarihi Oluk Köprü’yü geçerek Ebul Hasan Hanı ve oradan Manavgat'tan kuzeye çıkan Kembos Polyesi'nden geçen Beyşehir istikametine devam eden kervan yoluna bağlandığı anlaşılmaktadır (Harita 2).

Alaiye kıyı kesimini iç bölgeye bağlayan tescilli han ve kervansarayların bulunduğu ve buna bağlı olarak çizilen bir yol söz konusu değildir. Ancak toponimik verilerin yoğunlaşması gösteriyor ki bu saha da alternatif bir güzergâh mevcuttur. Alaiye'den kuzeye devam edip Toros Dağlarını aşan Konya ve Larende (Karaman) arasındaki ana artere bağlanan bir güzergâhtan söz edilebilir. Şöyle ki Alaiye kuzeyinde "Han Mevkii (3 adet)", "Banlıcahan", "Yenisaray", "Başhan", "Kervanpınar", "Baruthanı", "Çarşamba/Saray/Dinek", "Eskihan", "Kozverenhanı", "Kuvvettaşhanı", "Y1kıkhanı(Susuzhan1)", "Yarımcahanı", ve "Avratınhanı", “Adilhanı”, üzerinden Larende-Konya arasındaki kervan yoluna kavuşmaktadır (Harita 2).

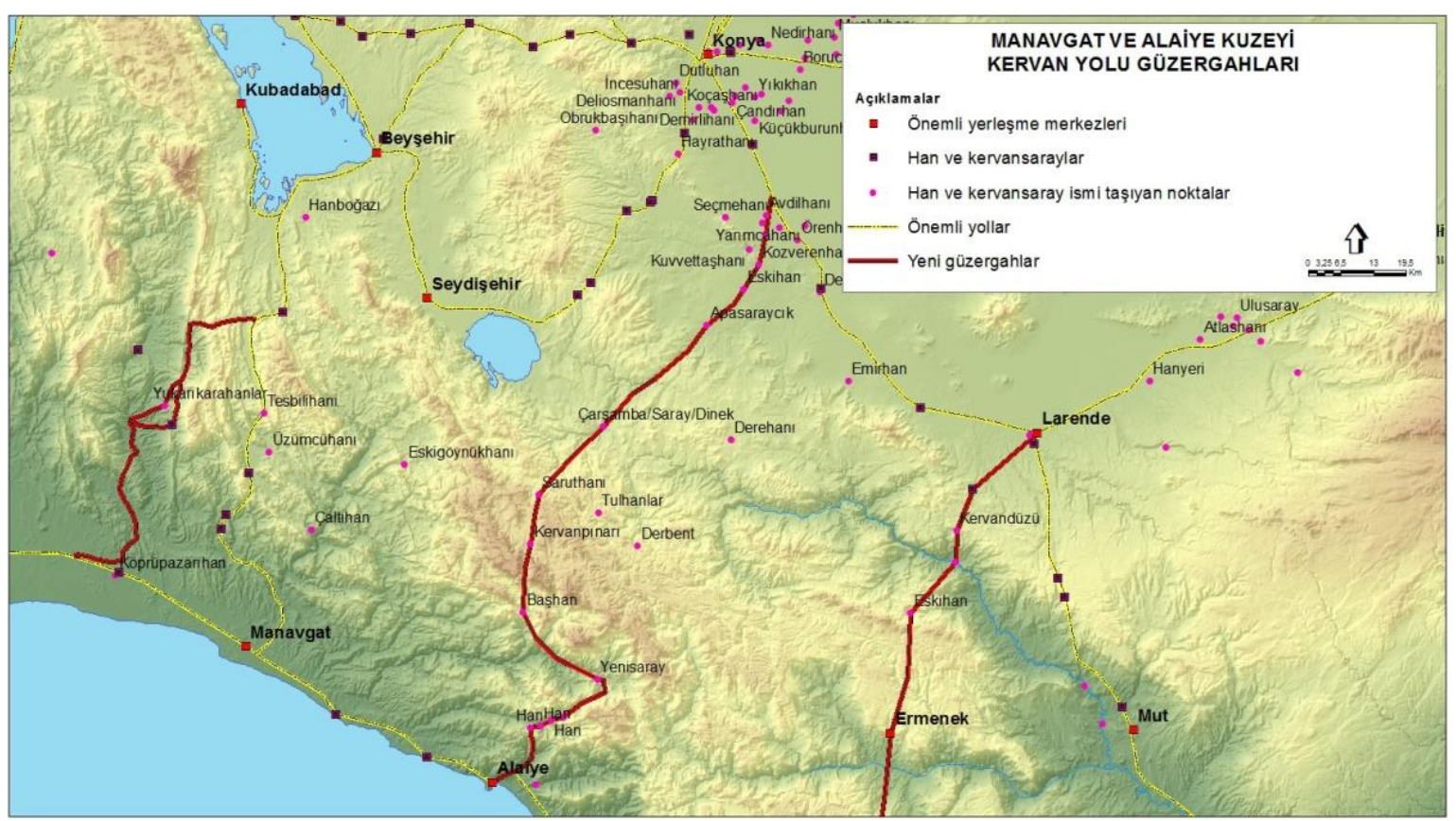

Harita 2: Manavgat ve Alaiye kuzeyi kervan yolu güzergâhları 
Anamur'dan kuzeye doğru alternatif bir yol güzergâhı söz konusu olup "Ala (Görmel) hanı", "Kervanalanı", Ermenek, "Eskihan”, "Kervandüzü", "Kozak hanı" (tescilli) üzerinden Larende'ye ulaşmaktadır. Tarsus'tan başlayan kervan yolu ise Pozantı'ya ulaştıktan sonra kuzeye doğru "Feneyhanı", "Yarataşhanı", "Beylikhanı", "Telithanı" üzerinden Niğde ve Kayseri arasındaki kervan yoluna bağlanmaktadır. Sis (Kozan)'den kuzeye doğru "Sultanhanı", "Kısıkhanı", "Uzakhanı", "Hanyeri" istikametini takip ederek Kayseri'den doğuya doğru devam eden kervan yoluna Hanköy (tescilli)'e kavuşan bir güzergâh mevcuttur (Harita 3).

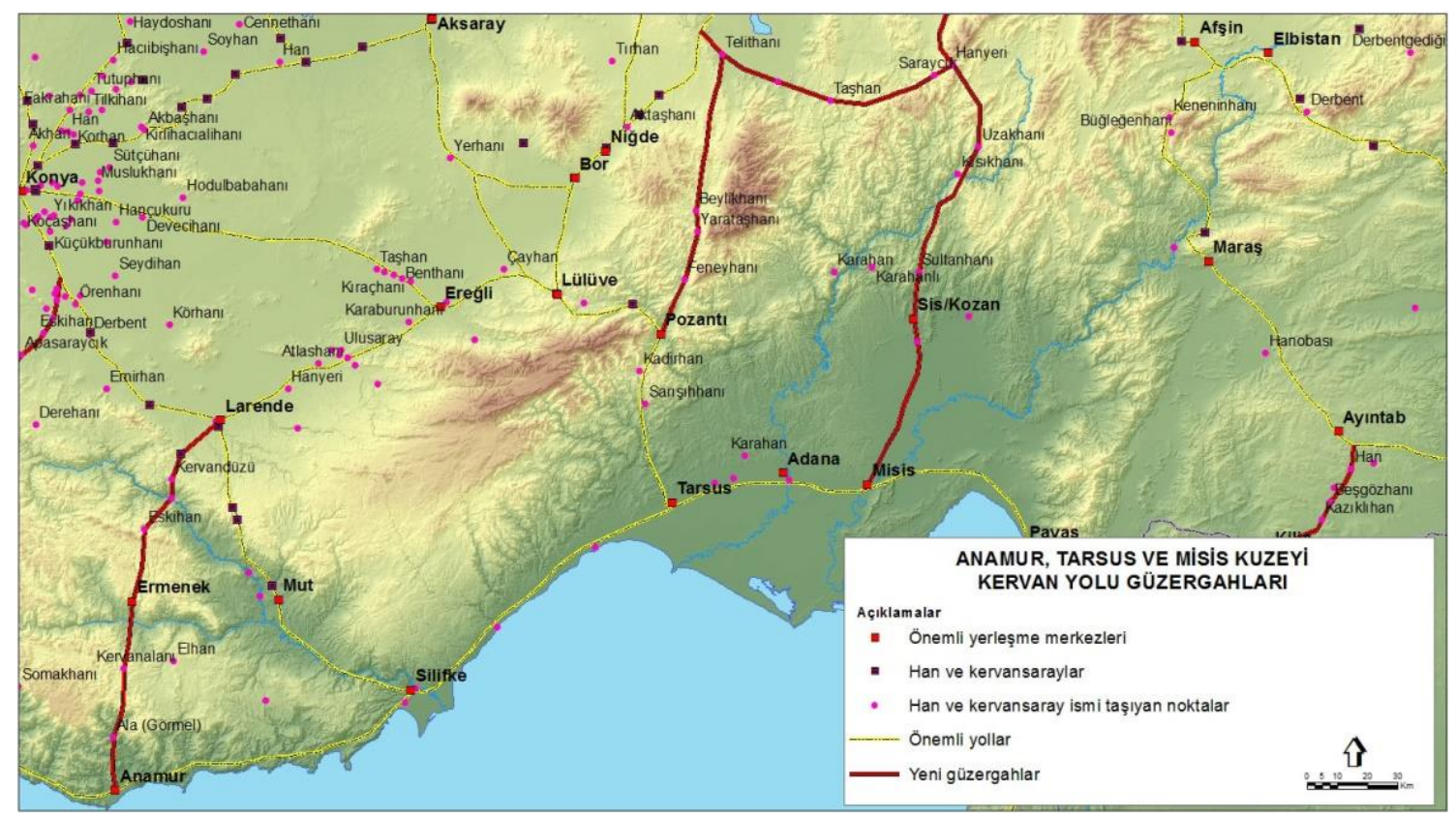

Harita 3: Anamur, Tarsus ve Misis kuzeyi kervan yolu güzergahı

Yukarıda toponimik verilerden hareketle belirtilen güzergâhlar sahada bilinenin dışında Akdeniz kuzey şeridini iç kesimlere bağlayan alternatif güzergâhların olduğunu göstermektedir. Sahada bu denli han ve kervansaray adlı/ekli yer ve yerleşme isminin mevcudiyeti tarihi süreçteki ulaşım arterlerinin bir simgesi olarak toponimik verilere yansıması olarak değerlendirilebilir.

\section{Doğu Karadeniz Kıyı Şeridini İç Bölgelere Bağlayan Kervan Yolu Güzergâhları}

Doğu Karadeniz kıyı şeridini iç bölgelere bağlayan güzergâhlar üzerinde bilinen herhangi bir tescilli han ya da kervansaray söz konusu değildir. Ancak yapılan taramalar neticesinde sahil şeridinin çeşitli alternatif güzergâhlar marifeti ile iç bölgelere bağlandığı görülmektedir. Bu sahada özellikle han adlı/ekli toponimik verilerin belirli hatlar dahilinde yoğunlaştı̆̆ görülmektedir. Topografya haritaları üzerinde yapılan taramalar neticesinde Doğu Karadeniz dağlarını aşan yedi güzergâhtan söz edilebilir. Bu yedi güzergâhtan birincisi Trabzon'un batısında Giresun-Şebinkarahisar arasındaki yoldur:

- Giresun-Şebinkarahisar hattı: Giresun, "Handibi”, "Han”, "Kuşluhan", "Tespihan", "Karıncahanları", "Kanlıhan”, “Asarcıkhan 1", “Asarcıkhan 2" Şebinkarahisar (Harita 4). 


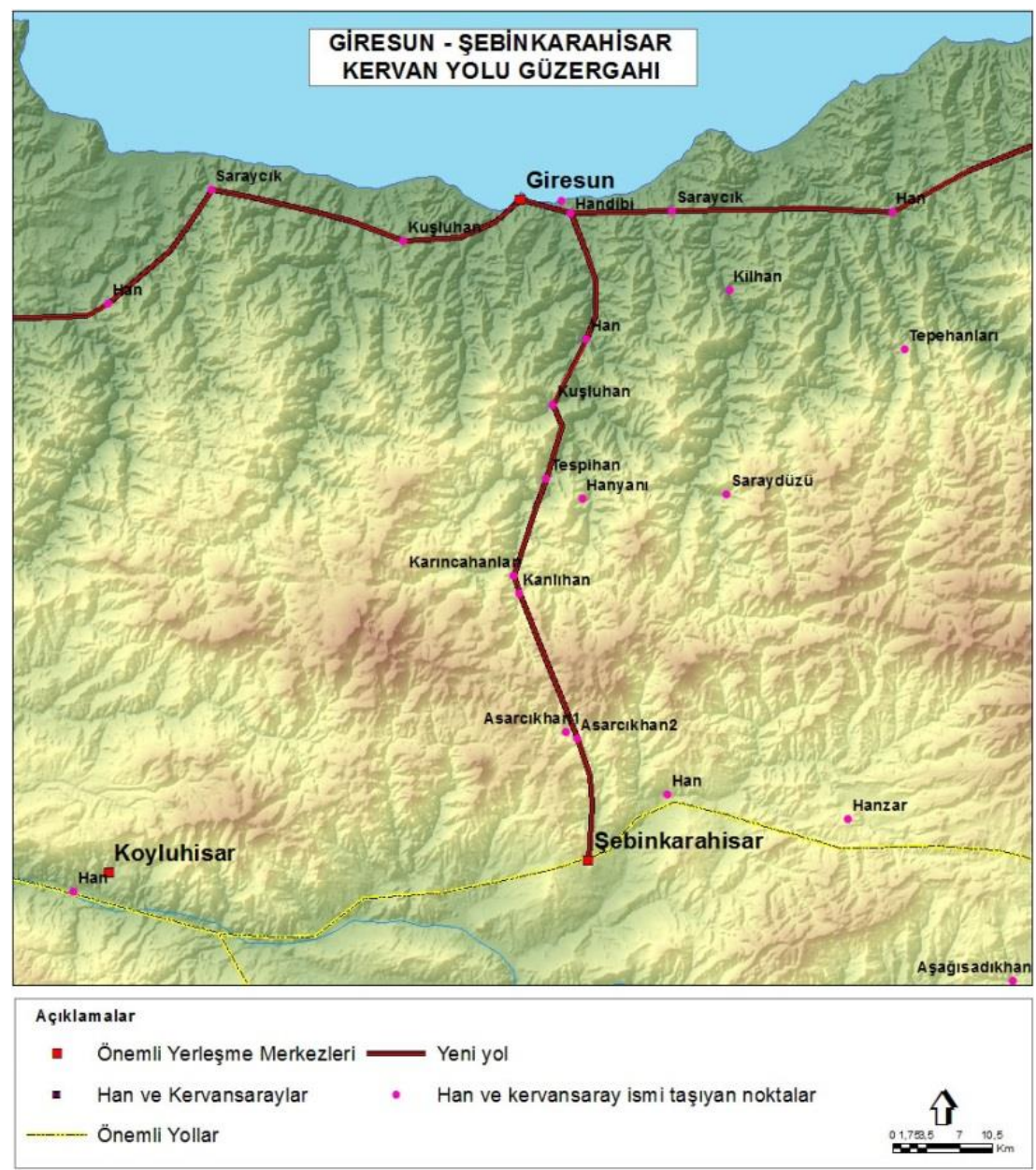

Harita 4: Giresun-Şebinkarahisar kervan yolu güzergahı

Doğu Karadeniz kıyı kesimini bağlayan diğer altı güzergâh Trabzon'un doğusunda yer almakta olup bu yollar şöyle sıralanabilir (Harita 5):

- Trabzon-Gümüşhane Doğusu bağlantısı: "Silhanı", "Sirhanlı", "Gümüşkihanı", "Kazıklıhanları", "Taşköprühanı", "Kazmacıhanı”, "Han”.

- Sürmene-Bayburt Kuzey Batısı bağlantısı: Sürmene, "Kilimlihan”, "Kahvedüzühanları", "Soğuksuhanları", "Ebehanları", “Ağaçbaşıhanları", "Taşlıhanları”, "Limonsuyuhanları", "Bendikhanları", "Vezirhanı".

- Of-Bayburt Kuzey-Kuzeydoğusu bağlantısı: Of, "Taşhan”, "Hanırmak”, Alçalı/Uzunköprü, "Handar", "Derbaşıhanı", "Cankurtaranhanı", "Han".

- İyidere-İspir bağlantısı: İyidere, "Han”, "Han”, "Taşeyrekhan”, "Şimşithanı”, "Han”, "Han”, İkizdere, "Bayırlıhan”, “Han”, “Tulumpınarhanları", “Han”, “Han”, “Küçükovithanı”, “Han”, "Han", İspir.

- Derepazarı-Tortum bağlantısı: Derepazarı, "Karayemişhanı", "Küçükçayırhanı", "Eskihan”, memişpaşahanı", "Başçayırhanı", "Kumhalahan”, "Kurtderehanı”, "Hanzera”, "Sürbehan”, Tortum.

- Hopa-Ardanuç bağlantısı: Hopa, "Düzhan,” Tekelihanı(Nigayhanı)”, "Kiremithanı”, "Katiphan", "Arsahanı", "Sünbülhanı", "Tolgonhanı", Altunsuhanı", "Berathanı", "Hamamlıhanı”, “Görgötöhanı”, “Ziverinhanı” Ardanuç. 


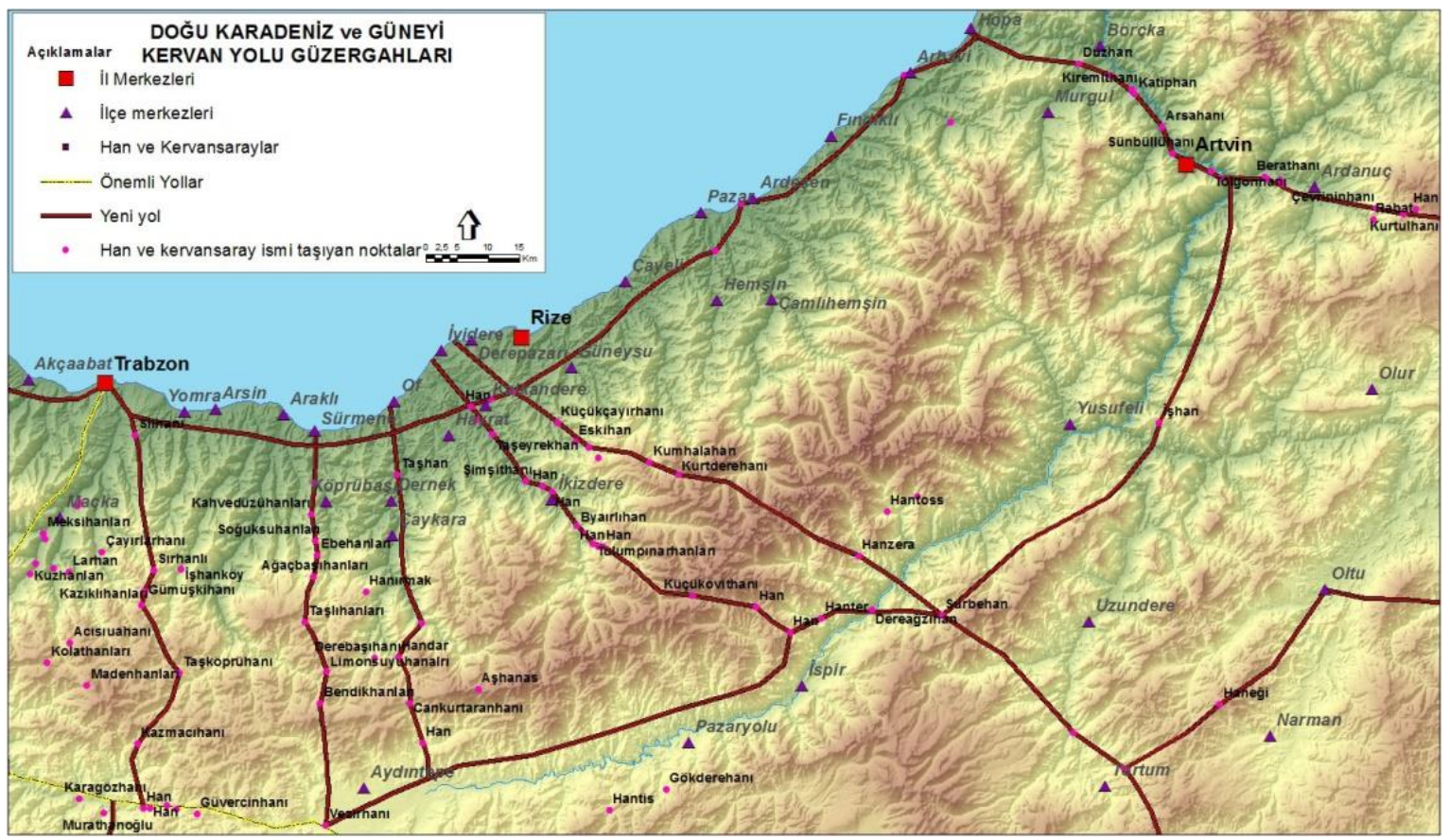

Harita 5: Doğu Karadeniz ve güneyi kervan yolu güzergahları

Doğu Karadeniz'de her ne kadar şu ana değin tespit edilebilen tescilli han ve kervansaray mevcut olmasa da bu sahada geçmişin ulaşım yadigârı olan han adlı/ekli yer ve yerleşme isimlerinin yaşadığı görülmektedir. Han adlı/ekli yer ve yerleşme isimlerinin yoğunluğunun bu denli fazla olmasının yanı sıra sahadaki tarihi ulaşım güzergâhlarının mevcut jeomorfolojik özellikler nedeniyle büyük ölçüde vadileri, doğal geçitleri ve sırtları takip ederek devam etmesi ayrıntılı yol çizimine imkân vermektedir.

\section{Amasra, Kastamonu, Sinop Çevresi ve Güneyi Kervan Yolu Güzergâhlart}

Amasra ile Sinop arasındaki sahil şeridini ve kıyının iç kesiminde yer alan Kastamonu, Gerede, Çorum ve Amasya gibi şehirleri daha güneye bağlayan çeşitli güzergâhlar söz konusudur. Tarihi süreçte sürekli önemli bir güzergâh olan İstanbul-İran yolu (Osmanlı döneminde sol kol) üzerinden kuzeye ve güneye bağlantı veren yolların yanı sıra alternatif bazı yollardan da söz etmek mümkündür. $\mathrm{Bu}$ sahada topografya haritalarından elde edilen toponimik verilerden hareketle çizilebilen ulaşım hatları şöyledir (Harita 6):

- Amasra-Gerede bağlantısı: Amasra, "Handıra", "Han", Çaycuma güneyi, "Oğuzhan", "Burhanoğlu”, Devrek, "Dorukhan", "Kaynarcahanı", Mengen, Gerede.

- Amasra-Safranbolu bağlantısı: Amasra, "Handıra", "Han”, "Han", "Dörtyolhanı", “Topalhasanhanı", "Soğuksuhanı”, “Ahmetustahanı”, Safranbolu.

- Dörtyolhanı-Kastamonu bağlantısı: "Dörtyolhanı", "Alhanlar", Eflani, "Demirhan", “Gülcününhanı”, Daday, "Hanköy”, "Han”, Kastamonu.

- İnebolu-Kastmaonu bağlantısl: İnebolu, "Solgunhanları”, "Döşemehanı”, "Han”, "Kervansaray", "Duransaray", "Han”, "Sirasöğütlerhanı", Kastamonu.

- Kastamonu-Tosya bağlantısı: Kastamonu, "Taşhan”, "hacıbeyhanı”, "Yenihan”, “Eskihan”, Tosya. 


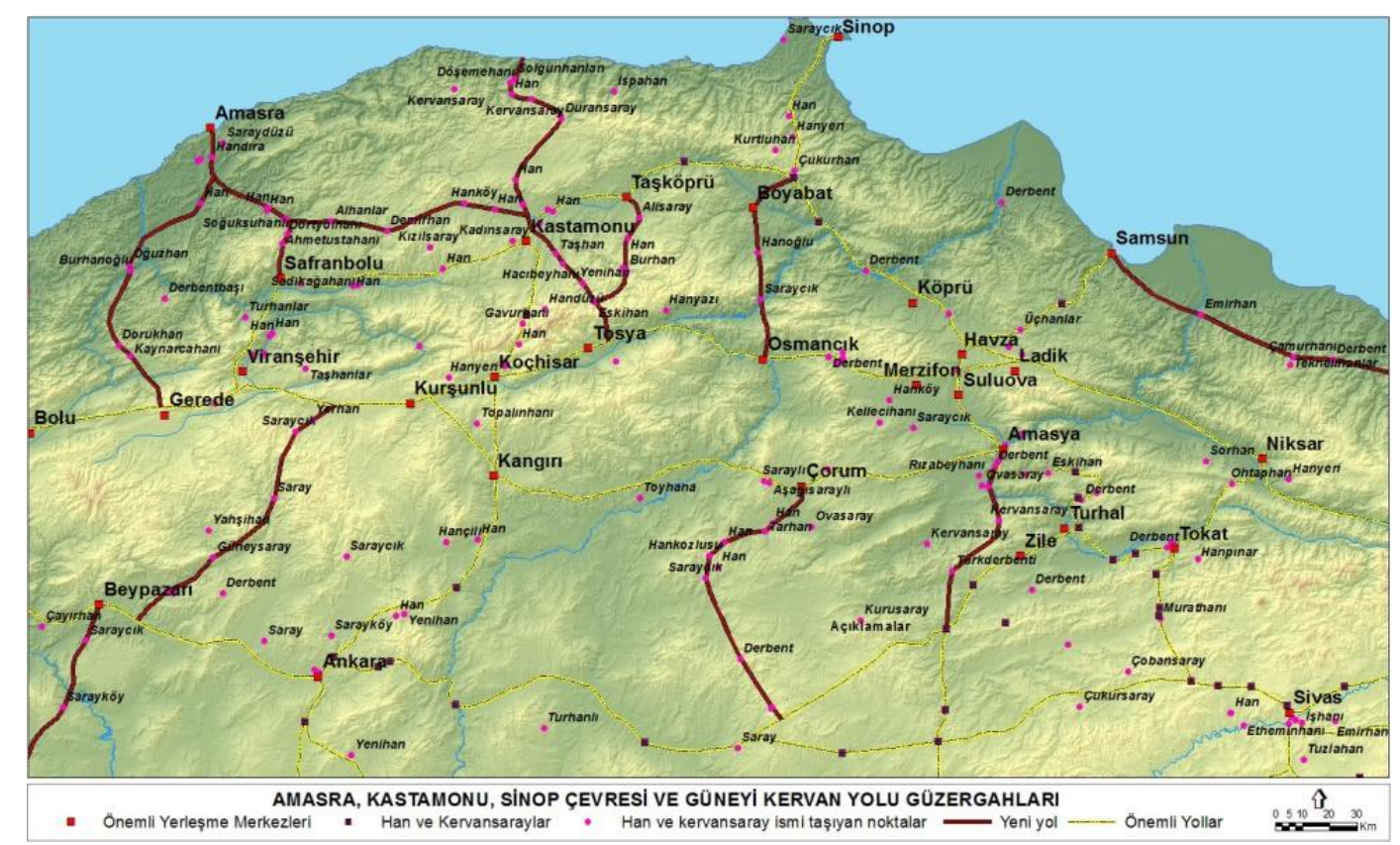

Harita 6: Amasra, Kastamonu, Sinop çevresi ve güneyi kervan yolu güzergahları

- Sinop-Osmancık bağlantısı: Sinop, "Han", "Hanyeri”, "Çukurhan (tescilli)", Boyabat, "Hanoğlu", "Saraycık", Osmancık.

- Çerkeş-Beypazarı bağlantısı: Çerkeş, "Saraycık”, "Saray”, Kızılcahamam, "Güneysaray”, "Eskköprü”, "Yeşilözköprüsü”, Beypazarı.

- Çorum-Sorgun bağlantısl: Çorum, "Han”, "Tarhan”, "Han”, "Hankozlusu”, "Han”, "Saraycık”, Boğazkale, "Derbent”, Şerefiye (Taşköprü), Sorgun.

- Amasya-Çekerek bağlantısı: Amasya, "Çağlayanköprüsü”, "Derbnet”, "Rızabeyhanı", “Ovasaray”, "kervansaray”, “Türkderbenti”, "Çekereksuyuhanı (tescilli)”, Çekerek.

Harita 6'da ve bununla ilgili olarak yukarıda verilen alternatif yollar doğu batı istikametinde ana arterin dışında kuzey-güney yönünde şehirler, kasabaları birbirine bağlayan tarihi ulaşım güzergâhlarını belirtmesi bakımından önem arz etmektedir. Söz konusu ulaşım hatlarının kıyı yerleşmelerini kara içinde kalan şehirlere bağladığı gibi kara içinde bulunan yerleşmeleri de birbirine bağlamak suretiyle ulaşım sisteminin tesis edildiği görülmektedir.

\section{Eskişehir, Bursa, Kütahya Çevresi Kervan Yolu Güzergahları}

Osmanlı İmparatorluğu zamanında Üsküdar'dan başlayarak Eskişehir üzerinden Konya, Adana, Antakya, Halep güzergâhını takip ederek Mekke'ye ulaşan yola "Hac yolu" ya da "sağ kol" ismi verilmekteydi. Hac yolunun da üzerinden geçtiği Eskişehir ve çevresinde çeşitli alternatif yolların olduğunu topografya haritalarında yer alan toponimik veriler göstermektedir. Bu sahada belirginleşen kervan yolu güzergâhları şu şekilde sıralanabilir (Harita 7):

- Beypazarı-Sergendanhanı (Kulu) bağlantısı: Beypazarı, "Saraycık", "Derbent", Sivrihisar, "Derbent", "Çakı1han", "Sırçasaray", "Kutluhan", "Sergendan hanı (tescilli)"

- Sivrihisar-Eskişehir bağlantısı: Sivrihisar, "Yenihan”, "Geleceksaray”, Eskişehir

- Seyitgazi-Altıntaş bağlantısı: Seyitgazi, "Üçsaray", "Beşsaray”, "Saraycık", "Hanyeri”, "Murathanlar", Altıntaş. 


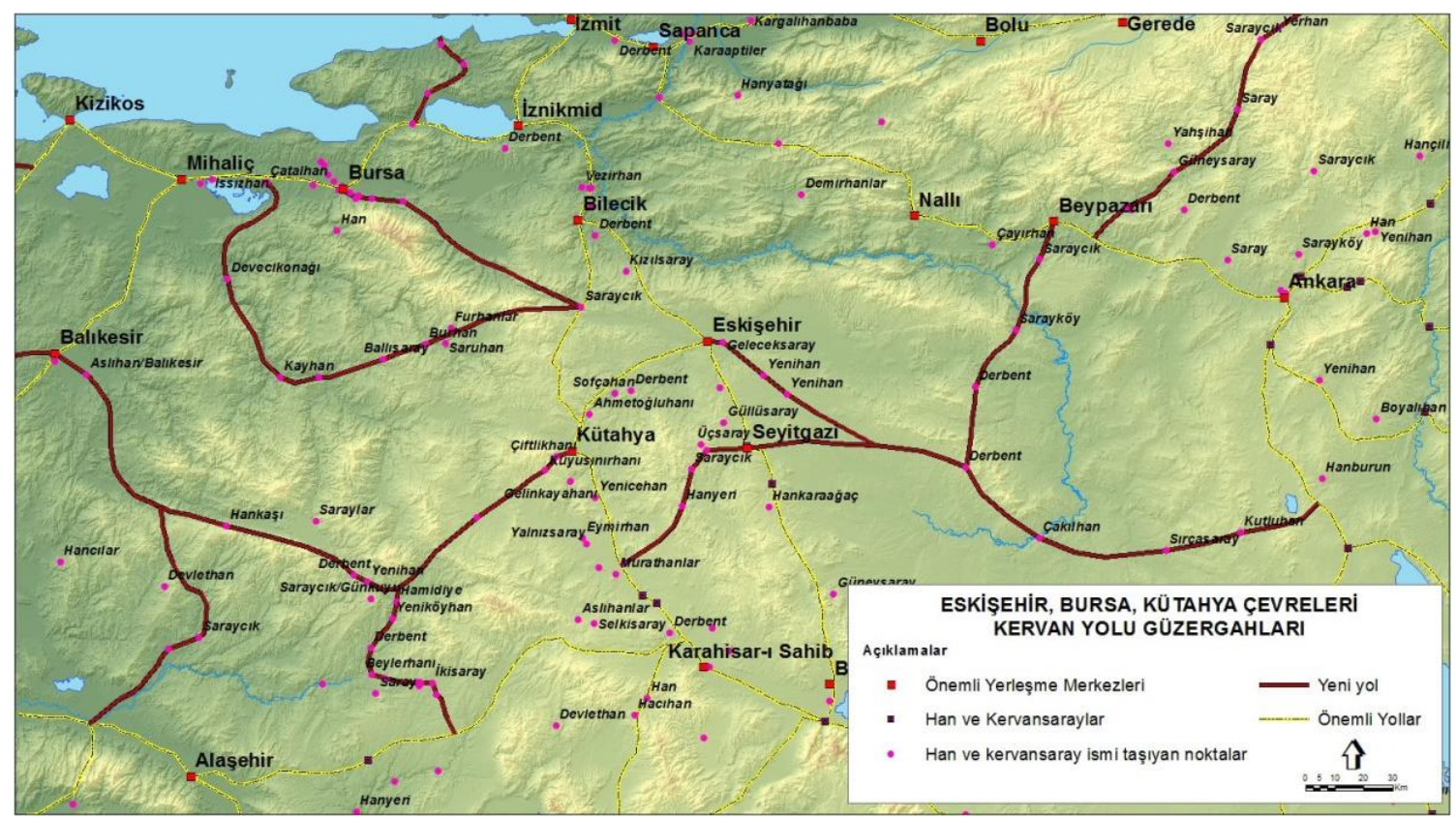

Harita 7: Eskişehir, Bursa, Kütahya çevreleri kervan yolu güzergâhları

- Kütahya-Gediz-Sivaslı bağlantısı: Kütahya, "Çiftlikhanı", "Kuyusınırhanı”, Çavdarhisar, Gediz, "Hamidiye”, Yeniköyhan”, "Derbent”, "Beylerhanı”, "Beylerhanı”, "Buğdaylıköprü”, "Halıpazarıköprüsü”, “Tabakhaneköprüsü”, "İkisaray”, Çanlıköprsü”, Sivaslı kuzeyi.

- Gediz-Balıkesir bağlantısı: Gediz, "Saraycık", "Yenihan", "Derbent”, Simav, "Hankaşı", Sındırgı, Bigadiç, “Aslıhan”, Balıkesir.

- Bozüyük-Bursa bağlantısl: Bozüyük, "Saraycık”, İnegöl, "Çukurköprü”, “Cilimbozköprüsü”, "Irgand1köprüsü”, “Tatarlarköprüsü”, Bursa.

- Bozüyük-Domaniç-Harmancık-Bursa batısı bağlantısı: Bozüyük, "Saraycık", Domaniç, "Furhanlar", "Saruhan”, "Burhan”, "Ballısaray”, Harmancık, "Yüreklikköprüsü”, “Kayhan”, "Devecikonă̆ı", "Çatalhan".

Bursa, Eskişehir, Kütahya, Balıkesir, Ankara ve Manisa arasında bilinen ana kervan yollarının dışında bu güzergâhlardan ayrılarak daha küçük ölçekli yerleşmeleri birbirine bağlayan kuzey-güney ve doğu-batı istikametli, ulaşım hatlarının olduğu görülmektedir. Böylece ana ulaşım arterlerine alternatifler ortaya çıkmakta ve tarihi kervan yolları daha da detaylanmaktadır.

\section{SONUÇ VE DEĞERLENDIRME}

Geçmişin araştırılmasında ilgili döneme ya da ilgili döneme yakın olan zaman dilimindeki kaynakların yanında bazen hiç verinin olmadığ 1 ya da günümüze ulaşmadığı durumlarda toponimik veriler geçmişin fiziki ve beşeri özelliklerinin ortaya çıkarılmasına imkân sağlayabilmektedir. Tarihi coğrafya çalışmalarının yanı sıra tarih, sanat tarihi, arkeoloji gibi bilim dalları için de toponimik veriler önemli bir veri kaynağı olarak belirtilebilir. Bu noktada farklı kaynaklardan elde edilecek toponimik verilerin dikkatle ele alınmasında ve değerlendirilmesinde fayda vardır.

1/200.000 ölçekli topografya haritalarında yapılan taramalar neticesinde 624 han, 4 kervan, 64 saray ve 7 kervansaray adlı/ekli yer ve yerleşme ismi tespit edilmiştir. Bugüne kadar Anadolu sathında Selçuklu dönemine ait 232 han ve kervansarayın ilgili bilim mensuplarınca ortaya konulmuştur. Elde edilen toponimik verilerin gösterdiği üzere 232'nin üstünde han ve kervansarayın mevcudiyetini göstermesi bakımından elde edilen bu bilgi önem arz etmektedir. Bugün bilim insanlarımızca tespit edilen han ve kervansarayların yanı sıra tescil edilmemiş/edilememiş ve mevcudiyeti şimdilik 
toponimik verilerden hareketle ortaya konulan bu bilgiler yeni araştırmaların yapılmasına ihtiyaç olduğunu göstermektedir.

Bilinen yolların ötesinde bazı sahalarda han ve kervansaray adlı/ekli yer ve yerleşme isimleri alternatif güzergâhların da mevcut olduğunu göstermektedir. Yapılan çizimlerle haritalarda gösterilen bu güzergâhlar üzerinde yapılacak arazi araştırmaları tarihi ulaşım sistemine katkılar sağlayabilecektir.

Ele alınan örneklem sahalarında görüldüğü üzere yeni alternatif güzergâhların toponimik delillerden hareketle çizilmesi mümkün olmaktadır. Yerelde yapılacak çalışmalarla bu güzergâhlar ülke sathında ve çizilen örneklem sahalarında artabilecektir.

Ayrıca örneklemler üzerinde sunulmaya gayret edilen toponimideki Selçuklu mührü yeni güzergâhların alternatif turizm olanakları (tarihi kültürel turizm, çeşitli yürüyüş rotaları gibi) bağlamında değerlendirilebilecektir.

\section{KAYNAKÇA}

\section{Topografya Haritaları:}

1/200.000 Ölçekli Adana, Akdağmadeni, Afyon, Akçakale, Akhisar, Aksaray, Akşehir, Alanya, Alaşehir, Amasya, Ankara, Antakya, Antalya, Artvin, Avanos, Aydın, Ayvalık, Bafra, Balıkesir, Bartın, Başkale, Beyşehir, Birecik, Bitlis, Bolu, Bursa, Çanakkale, Çankırı, Çıldır, Cizre, Çölemerik, Çorum, Denizli, Dinar, Divriği, Diyarbakır, Doğubeyazıt, Edirne, Edremit, Elazığ, Elbistan, Elmalı, Emirdağ, Ereğli, Erzincan, Erzurum, Eskişehir, Fethiye, Gazipaşa, Gerede, Giresun, Gürün, Halep, Hasankale, Hınıs, Hozat, Ilgın, İnebolu, Isparta-Burdur, İspir, İstanbul, İzmir, Kelemiş, Karaköse, Kars, Kastamonu, Kaş, Katrancı, Kayseri, Keskin, Kiğı, Kilis, Kırklareli, Kırşehir, Kocaeli, Konya, Konyaereğlisi, Kozan, Kuşadası, Malatya, Malazgirt, Manisa, Maraş, Mardin, Marmaris, Mersin, Midyat, Münbiç, Muradiye, Mut, Niğde, Nusaybin, Oltu, Orhaneli, Osmancık, Palu, Reşadiye, Rize, Safranbolu, Saimbeyli, Samsun, Şebinkarahisar, Şemdinli, Şile, Silifke ve Mersin Cenubu, Simav, Sinop, Sivas, Siverek, Sivrihisar, Tekirdağ, Trabzon, Ulukışla, Ünye, Urfa, Uzunköprü, Van, Yozgat, Zaho paftaları, Harita Genel Komutanlı̆̆l, Ankara.

\section{Araştırma Eserler:}

Acun, Hakkı. Anadolu Selçuklu Dönemi Kervansarayları. Ankara: Kültür ve Turizm Bakanlığı Yayınları, 2007.

Akalın, Şebnem. "Kervansaray". Türkiye Diyanet Vakfi İslâm Ansiklopedisi. 25/299-302. İstanbul: TDV Yayınları, 2002.

Çınar, Hüseyin - Bulut, Mehmet - Yiğit, İlker. “Tarihi İpek Yolu'nun Anadolu Güzergahı”. Uluslararası İpek Yolu Kongresi ve 10. ADAM Kongresi (27-29 Ekim 2013) Bildirileri. 123-150. İstanbul: İstanbul Sabahattin Zaim Üniversitesi Yayınları, 2014.

Darkot, Besim. Türkiye İktisadi Coğrafyası. İstanbul: İÜ Yayını, 1968.

Erdmann, Kurt - Erdmann, Hanna. Das Anatolische Karavansaray des 13. Juhrhunderts II-III, Berlin: 1976.

Erdmann, Kurt. Das Anatolische Karavansaray des 13. Juhrhunderts I, Berlin: 1961.

Gümüşçü, Osman - Yiğit, İlker. "XIII-XVI. Yüzyıllarda Beyşehir Çevresi Ulaşım Ağı". Uluslararası Orta Anadolu ve Akdeniz Beylikleri Tarihi, Kültürü ve Medeniyeti Sempozyumu-I Eşrefoğulları, (11-13 Eylül 2014 Beyşsehir). ed. Mehmet Şeker vd. 543-551. Konya: Necmettin Erbakan Üniversitesi Kültür Yayını, 2018.

Gümüş̧̋̈, Osman - Yiğit, İlker. "XI-XVI. Yüzyıllarda Cizre ve Çevresinde Ulaşım Ağı”. Uluslararası Bilim, Düşünce ve Sanatta Cizre Sempozyumu (14-15 Nisan 2012), Bildiriler Kitabı. ed. M.Nesim Doru. 9198, İstanbul: 2012.

Gümüşçü, Osman - Çınar, Hüseyin - Kılıç, Yusuf - Uğur, Abdullah. Açılamalı Türkiye Tarih Atlası Projesi (ATTAP). Ankara: TÜBİTAK, 2011.

Gümüşçü, Osman. XVI. Yüzyll Larende (Karaman) Kazasinda Yerleşme ve Nüfus. Ankara: Türk Tarih Kurumu, 2001. 
Halaçoğlu, Yusuf. “Anadolu/Ulaşım ve Yol Sistemi”. Türkiye Diyanet Vakfı İslâm Ansiklopedisi. 3/127-128. İstanbul: TDV Yayınları, 1991.

İlter, İsmet. Tarihi Türk Hanları. Ankara: Karayolları Genel Müdürlüğü, 1969.

Kesik, Muharrem. "Selçuklular Zamanında Anadolu”. Coğrafya. 146-148. Ankara: TÜSİAD Yayınları, 2002.

Özcan, Koray. “Anadolu'da Selçuklu Kentler Sistemi ve Mekansal Kademelenme”. METU. JFA, 23/2 (2006), 21-61

Özergin, M. Kemal. “Anadolu'da Selçuklu Kervansarayları”. İstanbul Üniversitesi Tarih Dergisi, XV/20 (1965) 141-170.

Tuncer, O. Cezmi. Anadolu Kervan Yollarl. Ankara: Vakıflar Genel Müdürlüğü Yayınları, 2007.

Turan, Osman. "Selçuklu Kervansarayları”. Belleten X/39 (1946) 471-496.

Türk Dünyası Kültür Atlası Selçuklu Dönemi 2. İstanbul: Türk Kültürüne Hizmet Vakfı Yayınları, 1998. 